\title{
Simplifying plant gene silencing and genome editing logistics by a one-Agrobacterium system for simultaneous delivery of multipartite virus vectors
}

\author{
Verónica Aragonés ${ }^{1}$, Flavio Aliaga ${ }^{1}$, Fabio Pasin ${ }^{2}$, and José-Antonio Daròs ${ }^{3}$ \\ ${ }^{1}$ IBMCP (CSIC-UPV), Valencia, Spain \\ ${ }^{2}$ Consejo Superior de Investigaciones Cientificas \\ ${ }^{3}$ Consejo Superior de Investigaciones Científicas (CSIC)
}

October 1, 2021

\begin{abstract}
Genome editing and gene expression engineering using CRISPR-Cas systems in plants usually rely on labor-intensive tissue culture approaches to generate stably transformed plants that express the components of the reaction. Viral vectors have demonstrated to be a quick and effective alternative to express multiple guide RNAs, DNA templates for homologous recombination, and even Cas nucleases. Here we have developed an improved vector system based on tobacco rattle virus (TRV) to simplify logistics in genome editing and gene silencing approaches. The new system consists in a single Agrobacterium tumefaciens clone co-transformed with two compatible mini binary vectors from which TRV RNA1 and an engineered version of TRV RNA2 are expressed. Sequences of recombinant proteins, gene fragments for virus-induced gene silencing (VIGS) or guide RNAs can be easily inserted by one-step digestion-ligation and homology-based cloning methods in the RNA2 plasmid to produce vectors with a size substantially smaller than usual. Using this new one-Agrobacterium TRV mini vector system, we show robust VIGS of an endogenous host gene after infiltration of bacterial suspensions at low optical densities, and efficient production of recombinant proteins in Nicotiana benthamiana. Most importantly, we also show highly efficient heritable genome editing in more than half of the seedling originating from inoculated N. benthamiana plants that express Cas9.
\end{abstract}

\section{Hosted file}

2021-09-15 Manuscript.docx available at https://authorea.com/users/424153/articles/540010simplifying-plant-gene-silencing-and-genome-editing-logistics-by-a-one-agrobacteriumsystem-for-simultaneous-delivery-of-multipartite-virus-vectors 
A Tobacco rattle virus

RNA 1

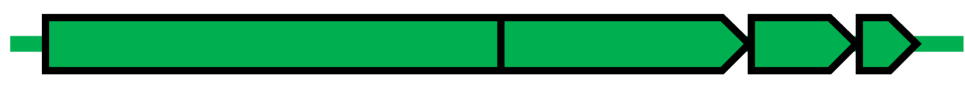

RNA 2

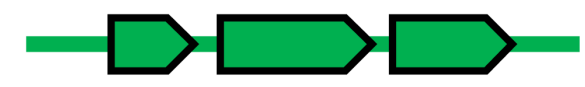

B
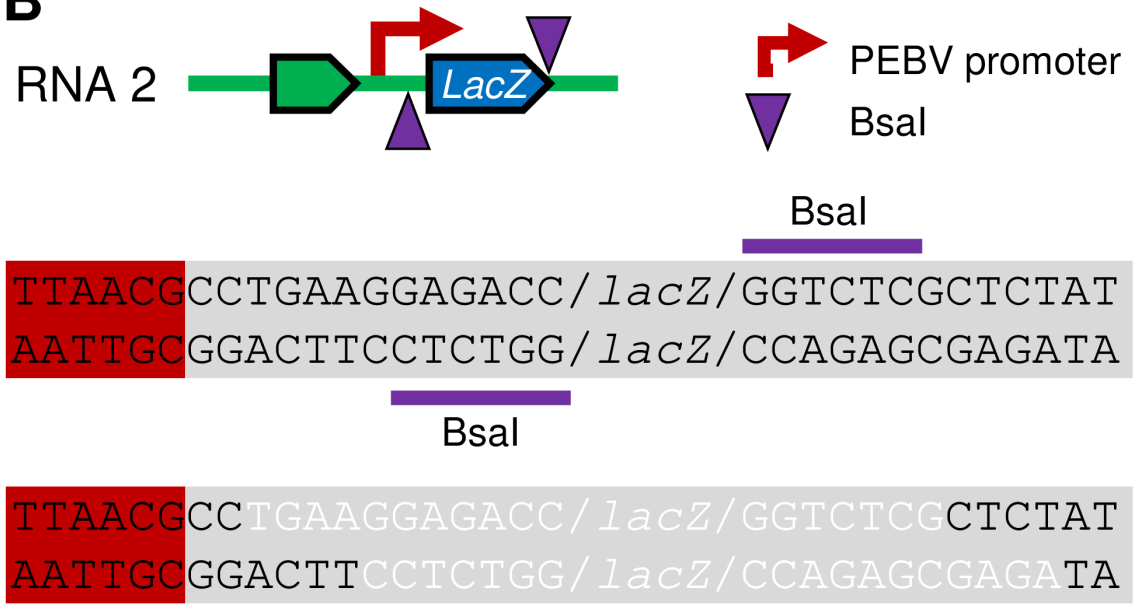

C

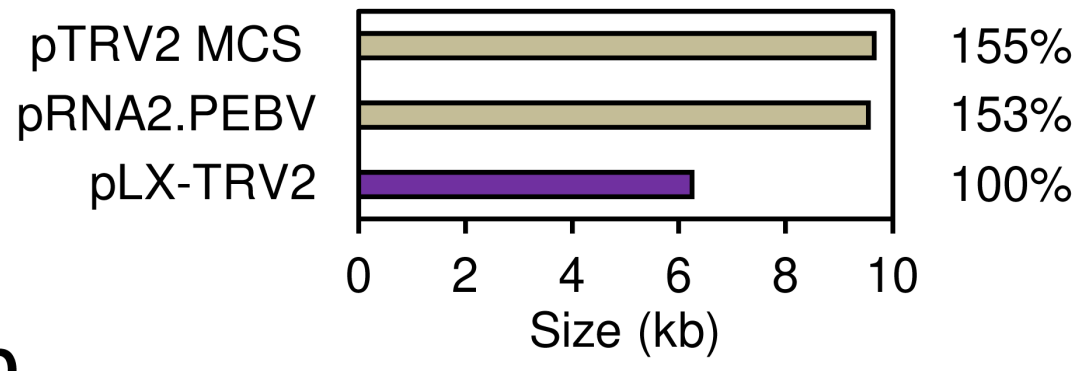

D

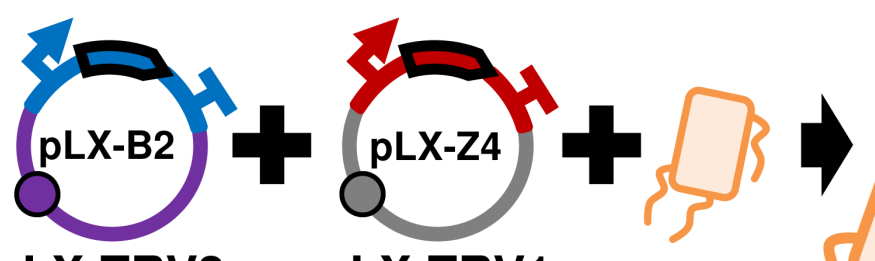
pLX-TRV2 pLX-TRV1 pBBR1 (nptl) ORK2 (aacC1)

Agrobacterium 1 strain/2 vectors 

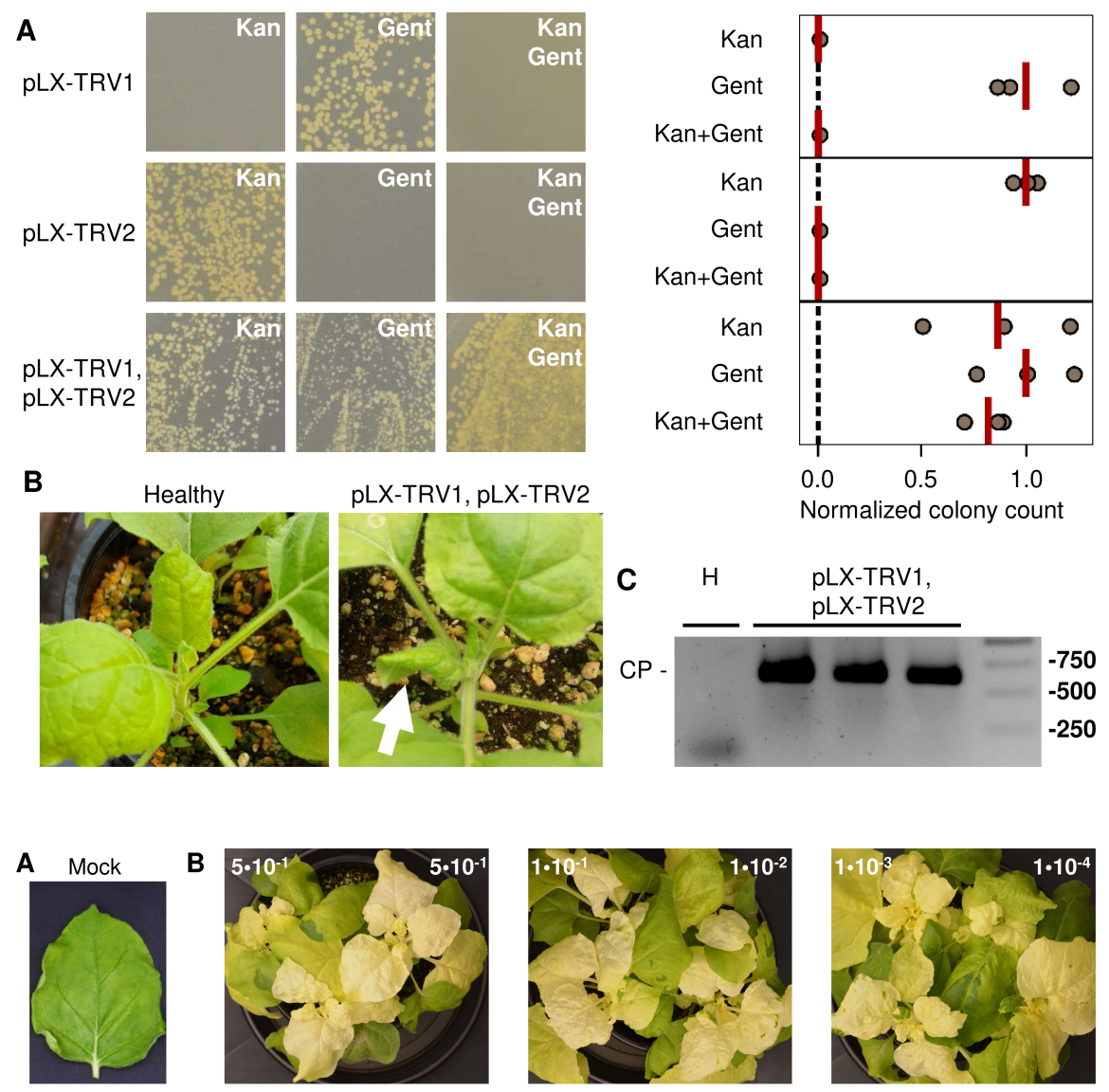

pLX-TRV1, pLX-TRV2-CHLI
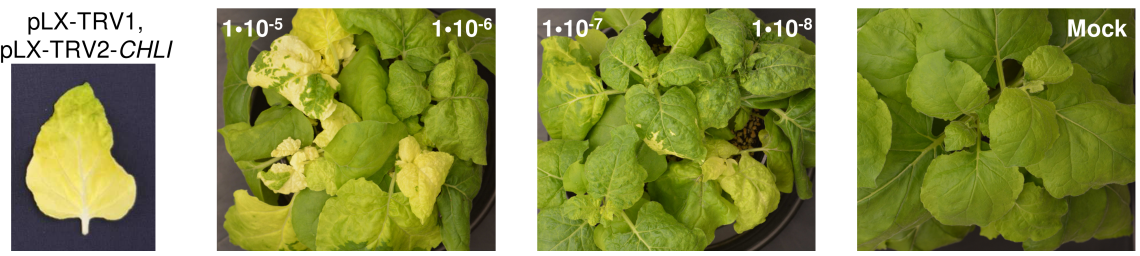
A

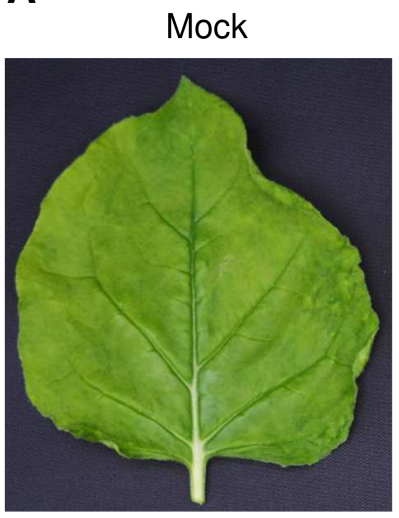

B
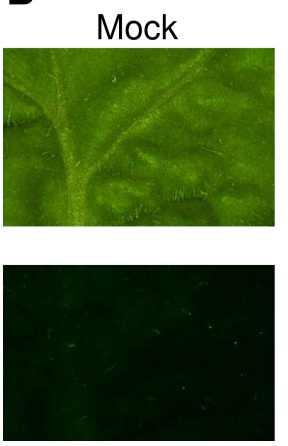

pLX-TRV1, pLX-TRV2-GFP
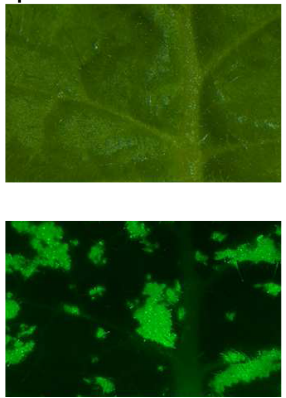

pLX-TRV1,

pLX-TRV2-GFP

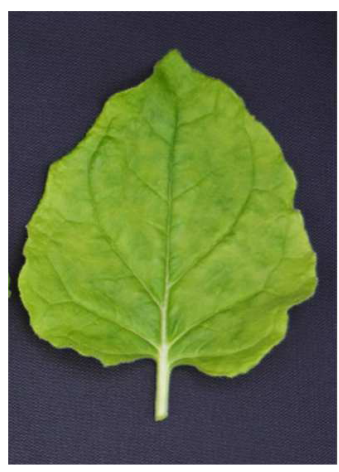

pLX-TRV1,

$M \frac{\text { pLX-TRV2-GFP }}{1 \mathrm{dpi} 3 \mathrm{dpi} 5 \mathrm{dpi}}$

32 -

23 -

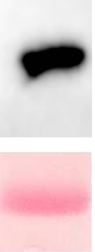


A

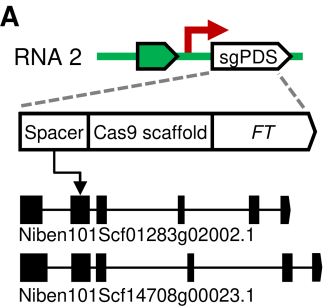

D

CTRL

$\mathbf{E}$

Niben101Scf01283g02002.1

Niben101Scf14708g00023.

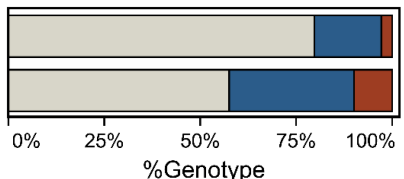

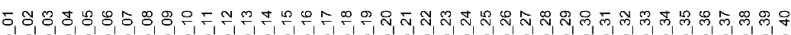

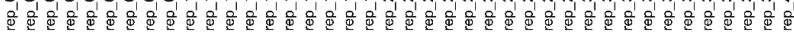

Niben101Scf01283g02002.1

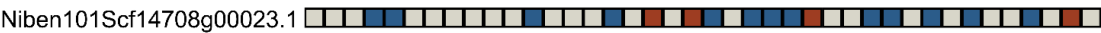

